Article

\title{
Applying the Modified Delphi Method and DANP to Determine the Critical Selection Criteria for Local Middle and Top Management in Multinational Enterprises
}

\author{
I-Chieh Hsu ${ }^{1}$, Yi-Ju Shih ${ }^{1, *(1)}$ and Fan-Yun Pai ${ }^{2, *}$ \\ 1 Graduate Institute of Human Resource Management, National Changhua University of Education, \\ Changhua 500, Taiwan; fbhsu@cc.ncue.edu.tw \\ 2 Department of Business Administration, National Changhua University of Education, Changhua 500, Taiwan \\ * Correspondence: lucyshi415@gmail.com (Y.-J.S.); fypai@cc.ncue.edu.tw (F.-Y.P.); Tel.: +886-9-1179-5500 \\ (Y.-J.S.); +886-4-723-2105 (ext. 7415) (F.-Y.P.)
}

Received: 2 August 2020; Accepted: 19 August 2020; Published: 20 August 2020

\begin{abstract}
Traditionally, multinational enterprises provided middle and top management from the mother country. They would only hire entry-level employees, such as workers, from the domestic country to control the subsidiary. However, local managers benefit from a shared background and culture with the local employees. Local managers can communicate and cooperate more effectively and smoothly with local employees than foreign mangers can. Therefore, multinational enterprises are increasingly selecting middle and top management from the local market. In this study, we aimed to determine the decision factors that influence the selection of local middle and top management from the perspective of human capital. We attempt to help multinational enterprises to choose and hire middle and top management from local markets. We first identified four dimensions and fourteen criteria according to the literature using the modified Delphi method. Then, DANP (decision making and trial evaluation laboratory (DEMATEL)-based analytic network process) was employed to determine the weights of each criterion or sub-criterion. Academic experts and top managers in multinational enterprises (Taiwanese companies in Vietnam) provided their opinions for data analysis. The results showed that positive psychological capital, managerial competencies, integration, and professional competencies were the four important factors that multinational enterprises consider when they select middle and top management from the local market. We further discussed the theoretical and practical implications of the results.
\end{abstract}

Keywords: selection criteria; middle and top management; human capital; DEMATEL-based ANP (DANP); modified delphi method

\section{Introduction}

The competitive advantage of multinational enterprises lies in its adaptable human capital, which determines whether the various activities of the enterprises can be executed with accuracy and efficiency. The literature widely supports that a positive relationship exists between human capital and corporate performance. Human capital is a crucial source of modern competitiveness, and a growing amount of importance is attached to it [1]. The greatest challenge that multinational enterprises face is the means of establishing a steady source of talent [2]. Thus, multinational enterprises are in greater need of international strategic human resource management when they are staffing, so that they can cultivate crucial talent to deal with various matters and achieve technology transfers. They must also attach importance to the local culture, economy, politics, and law. In some cases, the parent-company, 
third-country national, or expatriates may not be able to properly deal with local matters and may require host-country nationals to communicate, facilitate business operations, collect local intelligence, and offer experience with local laws and government policies.

Human capital is one of the primary indices of corporate learning and constitutes a key resource of enterprises [3]. Human capital helps enterprises obtain personal skills, knowledge, and the ability to organize teams and also serves as a stepping stone to the knowledge needed for individual entrepreneurship and innovative achievement [4]. Empirical research has shown that the traits, experience, skills, education, salaries, and rewards, management experience, and years of service of leadership all exert an impact on the management performance of enterprises [5]. The professional skills, knowledge, and innovative abilities of employees form external behaviors that create value for enterprises [6].

Multinational enterprises can lower operating costs by hiring local managers instead of expensive expatriates. Local managers are considered valuable human capital that offers knowledge regarding the local market as well as local business relations [7]. Empirical studies have examined employee localization models based on effort and found that the factors influencing employee localization were mainly associated with human resource management [8]. Recruitment and selection are the cores of recruitment and selection in multinational enterprises. The purpose of recruitment is to seek and obtain candidates with the potential to provide quality work, whereas selection aims to determine the requirements of the job position and then assess and decide which candidate should be hired for the position [9]. In multinational enterprises, employees are recruited and selected to handle the crucial coordination and control issues that international human resource management face and to bridge the gap between the parent-company and its subsidies in various geographical areas [10].

The majority of past studies on multinational enterprises examined expatriates or global staffing [11] or employee localization strategies [12]. Existing studies on localization focused on using human resource management practices (e.g., selection, programs, training, parent-company support, and the commitment of top management) to influence the degree of employee localization (Li et al., 2018). Few studies regarding employee localization in multinational enterprises discussed the use of local middle and top management, instead focusing on how the use of expatriates in emerging countries help multinational enterprises fill skill gaps, coordinate and control local operating costs, and facilitate control and communication [13].

We regarded the use of DANP (decision making and trial evaluation laboratory (DEMATEL)-based analytic network process) to examine the selection factors of local middle and top managers. The existing literature indicates that DANP is widely used in various fields, including the evaluation and formulation of knowledge management strategies, human capacity building, subcontractor selection, and information system selection. Although the scopes of these studies vary, the one thing they have in common is that they focused on solving problems involving multi-criteria decision making.

Research gaps still exist with regard to subsidiary employee localization in multinational enterprises. Past studies on the recruitment and hiring of middle and top management in multinational enterprises mostly used transaction cost theory to examine how middle and top management can bring better competitive advantages to corporate performance or used agency theory to investigate expatriate issues in middle and top management. Multinational enterprises have studied global talent management from the perspective of human capital [14]. This study aimed to clarify how multinational enterprises utilized the human capital perspective and DANP to examine the selection factors for middle and top management-assistant vice presidents, managers, and deputy managers. The empirical results in this study address gaps in the existing research.

In this study, we aimed to identify the criteria to select top and middle managers from local labor markets for multinational companies. We took Taiwanese companies as samples, and we analyzed how Taiwanese companies hire managers for their subsidiaries in Vietnam. We investigated how parent companies in Taiwan select top or middle managers from the local labor market in Vietnam. 
Therefore, we asked the managers in Vietnam subsidiaries for their opinions regarding the criteria for hiring local managers and the importance of these criteria.

\section{Literature Review}

\subsection{Human Capital Perspective}

The rise of scientific management has kept organizations focused on human capital when it comes to employees. The human resource capital attracts attention because the functions of innovative recruitment and selection, training and talent development, and salary and performance appraisal in human resource management all have impacts on corporate performance. Human capital includes knowledge, skills, and experience [15]. Companies tend to desire and heavily rely on employees that can create performance value for them, which has promoted the necessity and prevalence of the human capital perspective [16].

With the rapid transitions of the knowledge-based economy today, enterprises believe that not only are employees with knowledge, skills, expertise, experience, and the abilities to innovate and adapt necessary operation costs but also that they must possess human capital that can create knowledge value and performance value for the enterprise. Thus, only a grasp of the latest knowledge, innovations, and technological applications can seize the opportunity to become winners in this era of fierce knowledge operations.

The relevant literature shows that the accumulation of where personal human capital actively creates value forms enterprises, and the means by which enterprises allocate human capital can enhance their competitive advantages [17]. Unless human capital is allocated in a way that fits the strategic intentions of the organization, human capital will have little economic value, and enterprises are the sources of core value and creative performance that determine the rise and fall of the economy [18]. Enterprises use organizational capital to use human capital and individuals are placed in enterprises to clarify the connection between their placement and corporate performance $[19,20]$.

\subsection{Human Capital Theory}

Human capital is thoughtful capital; employees can use their own knowledge, competence, and attitude to create value for the enterprise they work for [21]. This capital is one of useful attributes that companies have and that are manifested in employees; it cannot be replaced with machines or fully described with pen and paper [22].

Roos et al. [21,23] divided human capital into three aspects: competence, attitude, and intellectual agility. Competence refers to the skills and knowledge of the employees. Attitude encompasses their motives, behavior, and morality. Intellectual agility refers to the abilities of the employees to innovate, adapt, imitate, and integrate. Ployhart and Moliterno [24] then conceptualized human capital as the resources of an enterprise. Such resources are generated from the knowledge, skills, abilities, and other traits (KSAOs) of individual employees. Human capital is the ability accumulated from the personal KSAOs of employees to achieve the goals of the enterprise [25]. According to previous studies, most researchers all agreed that human capital should include four dimensions and that these are competence, attitude, intellectual agility, and traits.

A shortage of scarce human capital from middle and top management exists in the labor market, and when usage costs are higher than replacement costs, arrangements should be tailored to the local conditions. Scarce human capital from middle and top management helps enterprises fundamentally change their value creation and adaptation to dynamic environments, which ultimately prompts middle and top management and the enterprises to appropriately create the optimal productivity and resources. Such employment relationships enlarge the scope (financial income) of the market and increase the bargaining power of the middle and top management in financial income distribution [26].

The new internet era has begun, and crucial and successful organizations are in the midst of rapidly updated knowledge. The flood of knowledge can be presented in widely varying forms, 
thereby necessitating navigation with a new commercial compass and the ability to act swiftly and flexibly in organizations. To enhance their transition agility, organizations require forward-looking indicators, whether they are from the organization or personal perspectives. People are forever the most basic resource of organizations, and the value of their existence lies in their knowledge, skills, experience, abilities, personal traits, attitude, and commitment. These factors can create more valuable performance and productivity and transform into the implicit intellectual capital of the organizations.

In summary of the discourse presented by the numerous scholars above, in this study, we use the human capital defined by competence, attitude, intellectual agility, and traits of the employees as four dimensions to select middle and top managers for foreign companies in local markets. Employees are the most dynamic human assets in enterprises. The selected middle and top management can create wealth and performance for enterprises, lead the organization with efficiency, and make breakthroughs in this ever-changing new era of intelligence.

\subsection{Selection Criteria}

Based on the definition of human capital, four dimensions are identified. We surveyed criteria corresponding to each dimension.

\subsubsection{Competence}

The competence of management is different from that of entry-level employees. We, therefore, divided competence into three criteria: core competencies, managerial competencies, and professional competencies. Core competencies are the crucial competencies that all organization members need to have. Managerial competencies are competencies that managers on all levels should have. Professional competencies are specific competencies needed to efficiently achieve everyday tasks and work goals [21,23,27].

\subsubsection{Attitude}

An individual's attitude is closely associated with his or her character and trustworthiness. It is difficult for an organization to alter an individual's initial attitude; they can only use organizational culture to imperceptibly adjust an individual's emotions toward the organization and his or her organizational identification. Attitude also includes the performance value generated by the behaviors of individuals while they work. To reach the strategic goals of the organization, they work hard to overcome seemingly unsolvable problems to demonstrate their commitment and engagement, which is also due to the presence of motives [21,23]. There are five underlying criteria of attitude: engagement, achievement motivation, trustworthiness, emotional commitment, and organizational identification from relevant literature [28-31].

\subsubsection{Intellectual Agility}

Intellectual agility enables organizations to successfully progress towards diverse objectives, and it is closely associated with competence. If competence is the hardware connotation of human capital, then intellectual agility is the knowledge and skills installed within the hardware. During work or learning processes, more knowledge and skills are continuously added or updated. Intellectual agility can create reciprocity that facilitates the development of intellectual capital. Intellectual agility can be further divided into four abilities: innovation, adaptation, imitation, and integration [21,23,32,33].

\subsubsection{Traits}

Traits are personality traits or personal characteristics that appeal to other people under unique circumstances rather than the circumstances themselves. As mentioned in the section on attitude, an individual's attitude is closely associated with his or her character, that is, his or her personality traits, particularly the personality traits of management. A trait is persistent and plays a steady and profound role in life [34]. For middle and top managers, positive psychological capital $[35,36]$ and an 
internal locus of control [37-39] are quite critical. These two traits are found in successful managers. The selection factors of this study are shown in Table 1.

Table 1. Selection factors for middle and top management.

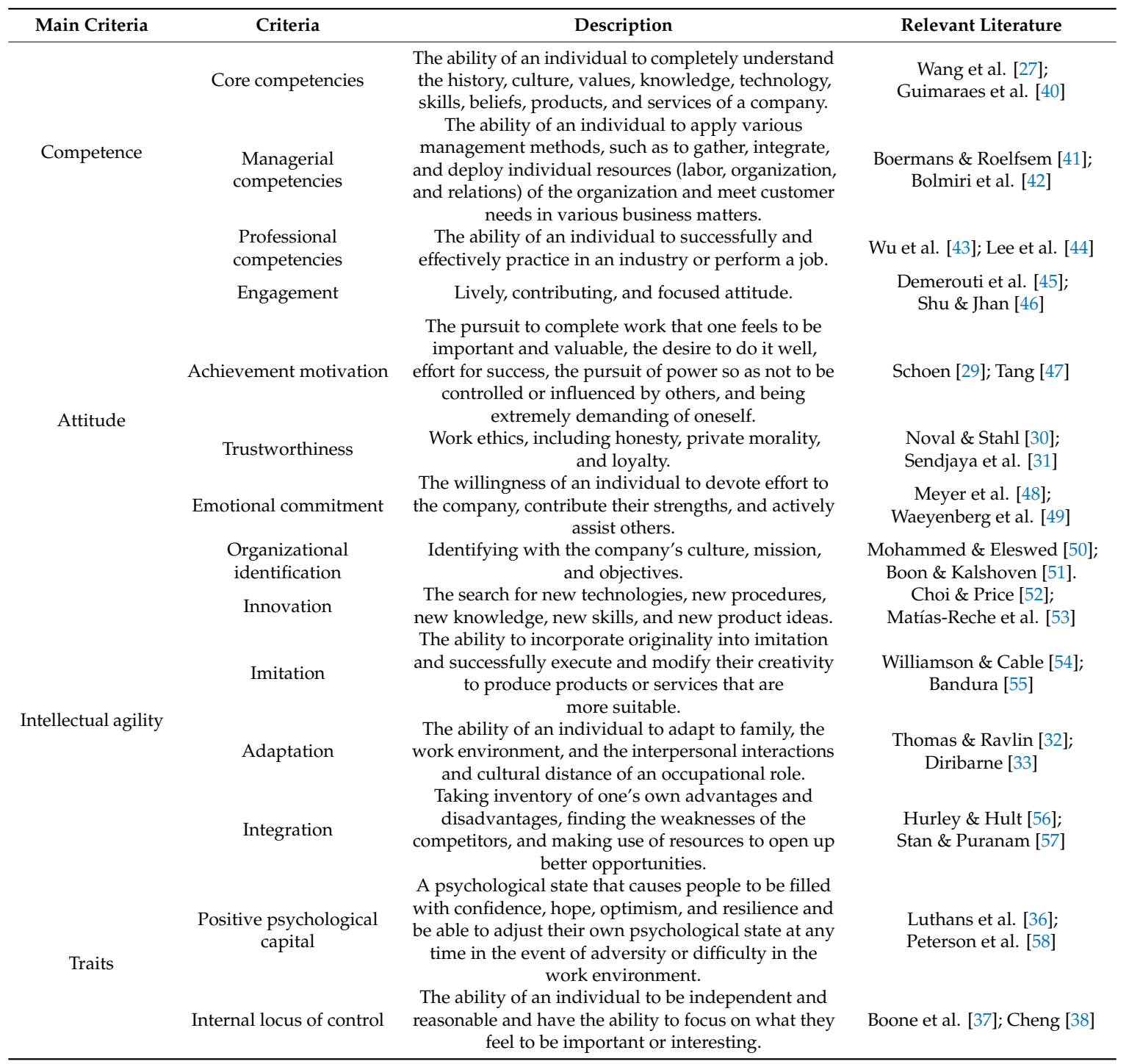

\section{Materials and Methods}

\subsection{Research Framework}

This study used the perspective of human capital to examine the selection factors for middle and top management in multinational enterprises. We first compiled the main dimensions and sub-dimensions based on the existing literature and the modified Delphi method. After all dimensions and sub-dimensions were determined, a DANP analysis structure was established. DANP questionnaires were designed and distributed to experts. The collected data was calculated to determine the weights of each sub-criterion. Figure 1 displays the research framework of this study. Figure 2 displays the initial criterial structure to select local middle and top management for multinational enterprises from the literature review. 


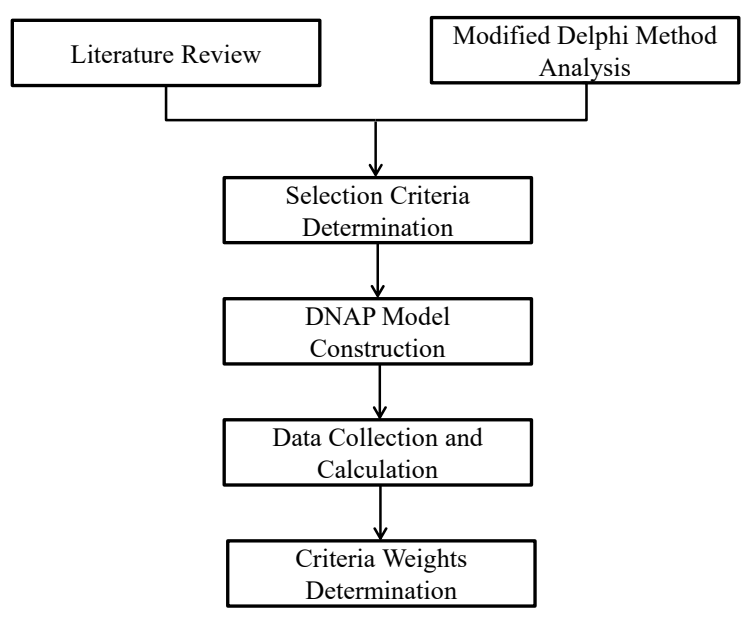

Figure 1. Our research process.

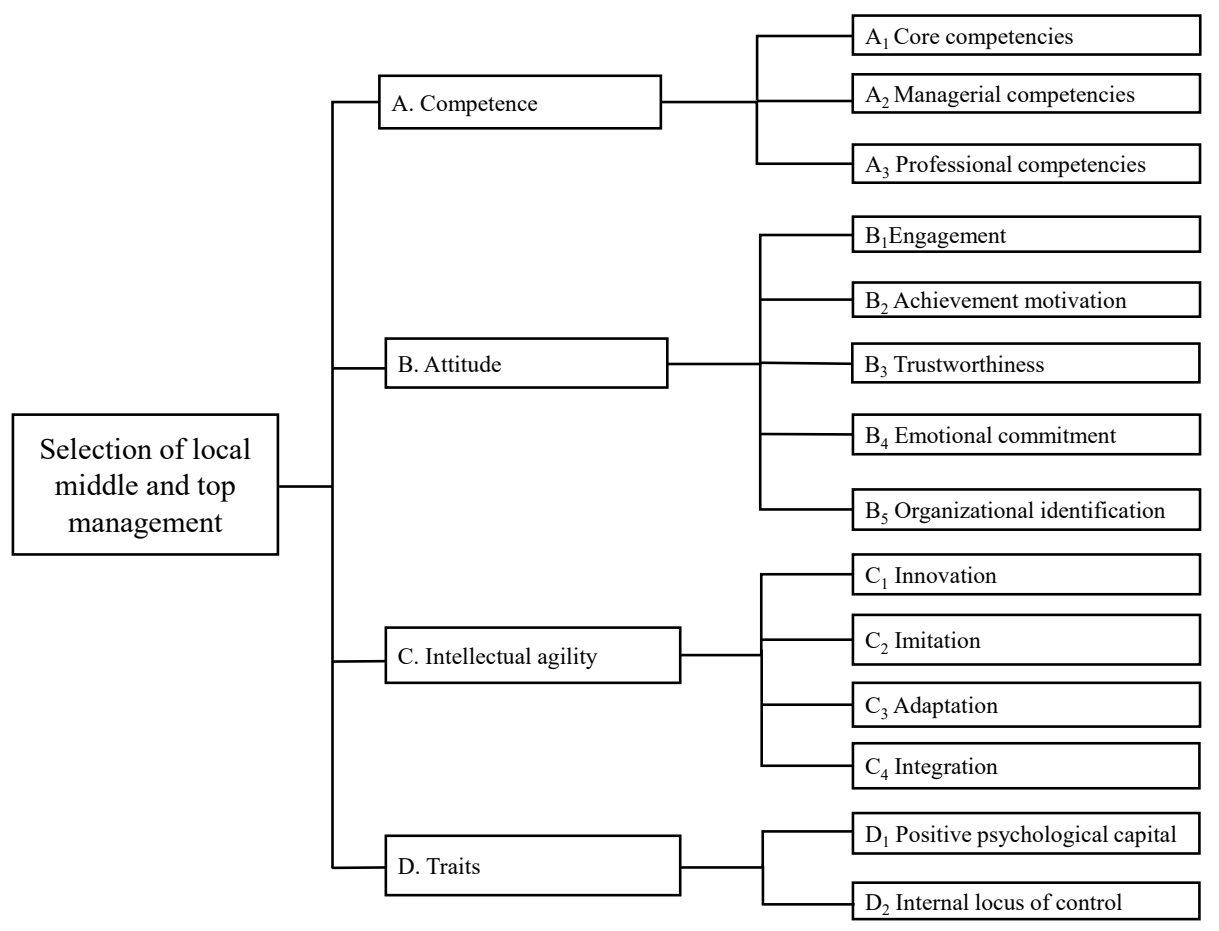

Figure 2. The initial dimensions and criteria framework.

\subsection{Modified Delphi Method}

Murry and Hammons [59] proposed the modified Delphi method. The relevant implementation methods and statistical methods are roughly the same as those in the conventional Delphi method, maintaining the spirit and merits of the original Delphi method. Experts can anonymously express and exchange opinions, and the complex questionnaire process was simplified; the complex open questionnaire survey in the first round was replaced with a structured questionnaire developed from the relevant results in the reference literature, the researcher's plans, or interviews with experts. This made the research work go more smoothly, saved time, and enabled the participating experts to focus on the research topic without the speculations in an open questionnaire. It also increased the questionnaire recovery rate and allowed the experts to reach a consensus. Using the experience of experts and researchers to establish credible opinions and examine related topics solves problems encountered in the conventional Delphi method [60]. 
In order to identify the dimensions and criteria consensus from the experts, we adopted the modified Delphi method to examine the selection dimension and criteria for middle and top management. As mentioned previously, the greatest difference in the modified version is the removal of the open questionnaire, which is time-consuming and often receives mixed opinions. Instead, a structured questionnaire was developed based on a large quantity of relevant literature. In the questionnaire of the modified Delphi method, selection criteria or sub-criteria with a mean greater than or equal to 4 and a coefficient of variation less than or equal to 0.5 were reserved and included in the DANP questionnaire.

\subsection{Dematel-Based ANP}

DANP (DEMATEL-based analytic network process) is a combined application of the decision making and trial evaluation laboratory (DEMATEL) and the analytic network process (ANP). In the first phase, DEMATEL was employed to confirm the influences among the main dimensions and the criteria and the magnitudes of these influences. ANP was incorporated into the second phase to obtain the weights between the criteria to confirm their degree of importance.

We referred to the DANP processes and equations employed by Hsu et al. [61], Hsu et al. [62], Chang et al. [63], and Wu and Chang [64]. The details of this method are as follows:

Step 1: Calculate the average matrix $G_{D}$.

Suppose that there are $H$ knowledge-based experts and $n$ dimensions/criteria. Based on the pair comparison results, the influence of dimension $i$ on dimension $j$ denotes $g_{i j}$. A non-negative $n \times n$ matrix can be shown as Equation (1).

$$
G_{D}^{k}=\left[\begin{array}{ccccc}
0 & \cdots & \cdots & \cdots & g_{i j}^{k} \\
\vdots & 0 & & & \vdots \\
\vdots & & 0 & & \vdots \\
\vdots & & & 0 & \vdots \\
g_{i j}^{k} & \cdots & \cdots & \cdots & 0
\end{array}\right]
$$

The average matrix $A_{D}$ of the dimensions can be obtained as shown in Equations (2) and (3).

$$
\begin{aligned}
A_{D} & =\left[\begin{array}{cccc}
a_{11} & a_{12} & \cdots & a_{1 j} \\
a_{21} & a_{22} & \cdots & a_{2 j} \\
\vdots & \vdots & \ddots & \vdots \\
a_{i 1} & a_{i 2} & \cdots & a_{i j}
\end{array}\right] \\
\text { where } a_{i j} & =\frac{1}{H} \sum_{k=1}^{H} x_{i j}^{k}, k: \text { the expert. }
\end{aligned}
$$

Step 2: Calculate the normalized initial direct-relation matrix $D_{D}$.

The normalized initial direct-relation matrix of the dimensions can be expressed as $D_{D}=\left[d_{i j}^{k}\right]$. First, we can calculate the positive scalar $S_{D}$ using the average matrix $A_{D}$, as shown in Equation (4).

$$
v_{D}=\max \left(\max _{1 \leq i \leq n} \sum_{j=1}^{n} a_{i j}, \max _{1 \leq j \leq n} \sum_{i=1}^{n} a_{i j}\right)
$$

$$
D_{D}=\frac{A_{D}}{v_{D}} \text {. Each element in matrix } D_{D} \text { falls between zero and one. }
$$

Step 3: Calculate the total relation matrix $T_{D}$. 
The total relation matrix, $T_{D}=\left[t_{i j}\right]$, is obtained using Equation (6), where $I$ is the identity matrix.

$$
T_{D}=D_{D}\left(I-D_{D}\right)^{-1}
$$

In addition, we must compute the $r$ and $c$ respectively, as shown in Equations (7) and (8), where $r_{i}$ is the sum of row $i$ and $c_{i}$ is the sum of column $i$. In a sense, $\left(r_{i}+c_{i}\right)$ represents the "prominence" of the main dimensions $i$, and the greater prominence indicates a greater degree of importance. In contrast, $\left(r_{i}-c_{i}\right)$ represents the "relation" of main dimensions $i$, which is the contribution of the dimension to the overall framework. $\left(r_{i}-c_{i}\right)>0$ indicates that the dimension is a net causer, whereas $\left(r_{i}-c_{i}\right)<0$ indicates that it is a net receiver.

$$
\begin{aligned}
& r_{i}=\left[r^{i}\right]_{n \times 1}=\left(\sum_{j=1}^{n} t_{i j}\right)_{n \times 1} \\
& c_{i}=\left[c^{j}\right]_{n \times 1}^{\prime}=\left(\sum_{i=1}^{n} t_{i j}{ }^{\prime}{ }_{1 \times n}\right.
\end{aligned}
$$

Step 4: Calculate the normalized total relation matrix $T_{D}^{\alpha}$.

The normalized total relation matrix $T_{D}^{\alpha}$ can be obtained by Equation (9).

$$
T_{D}^{\alpha}=\left[\begin{array}{ccccc}
t_{11} / r_{1} & \cdots & t_{1 j} / r_{1} & \cdots & t_{1 n} / r_{1} \\
\vdots & & \vdots & & \vdots \\
t_{i 1} / r_{2} & \cdots & t_{i j} / r_{2} & \cdots & t_{1 n} / r_{2} \\
\vdots & & \vdots & & \vdots \\
t_{n 1} / r_{n} & \cdots & t_{n j} / r_{n} & \cdots & t_{n n} / r_{n}
\end{array}\right]^{\prime}=\left[\begin{array}{ccccc}
t_{11}^{\alpha} & \cdots & t_{1 j}^{\alpha} & \cdots & t_{1 n}^{\alpha} \\
\vdots & & \vdots & & \vdots \\
t_{i 1}^{\alpha} & \cdots & t_{i j}^{\alpha} & \cdots & t_{1 n}^{\alpha} \\
\vdots & & \vdots & & \vdots \\
t_{n 1}^{\alpha} & \cdots & t_{n j}^{\alpha} & \cdots & t_{n n}^{\alpha}
\end{array}\right]
$$

Step 5: Calculate the weighted matrix $W_{D}$ of dimension.

Transposing the normalized total relation matrix $T_{D}^{\alpha}$ gives the weighted matrix $W_{D}$ as shown in Equation (10).

$$
W_{D}=\left[T_{D}^{\alpha}\right]^{\prime}
$$

Step 6: Calculate the limited weighted matrix $W_{D}^{L}$ of dimension.

After multiplying the weighted matrix $W_{D}$ by itself multiple times, we can obtain the limited weighted matrix $W_{D^{\prime}}^{L}$ as shown in Equation (11). The results of the limited weighted matrix $W_{D}^{L}$ are the weights of the main criteria.

$$
W_{D}^{L}=\lim _{k \rightarrow \infty} W_{D}{ }^{k}, k \in N
$$

Step 7: Calculate the normalized total relation matrix $T_{C}^{\alpha}$ of criteria.

After step 6, the total relation matrix $T_{D}^{\alpha}$ of the sub-dimensions should be computed. $d_{i}^{m n}$ should be calculated by Equation (12) and then we can obtain $T_{D}^{\alpha}$ by Equation (13).

$$
d_{i}^{m n}=\sum_{j=1}^{n} t^{i j}
$$




$$
\begin{aligned}
& \begin{array}{cccc}
D_{1} & D_{2} & \cdots & D_{N} \\
C_{11} \cdots C_{1 m_{1}} & C_{21} \cdots C_{2 m_{2}} & \cdots & C_{n 1} \cdots C_{n m_{n}}
\end{array}
\end{aligned}
$$

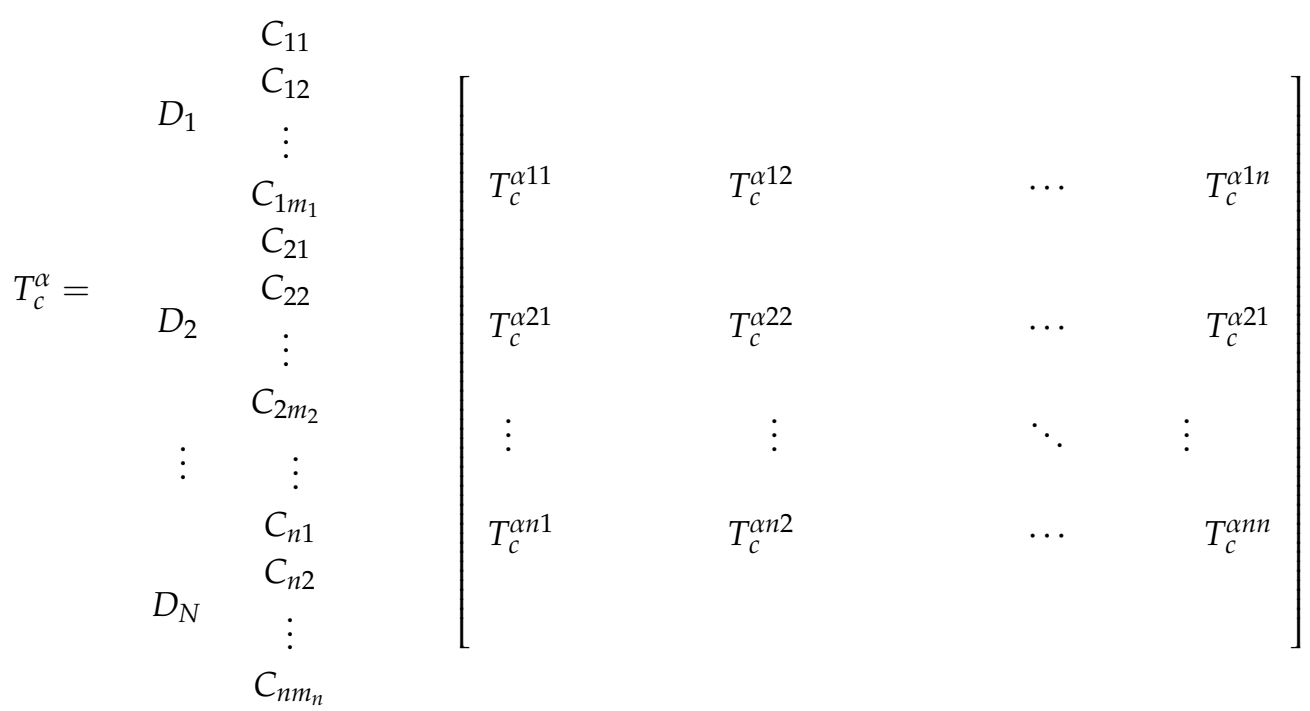

Step 8: Calculate the unweighted supermatrix $W$ of criteria.

The unweighted supermatrix $W$ can be obtained as shown in Equation (14).

$$
\begin{array}{cccc}
D_{1} & D_{2} & \cdots & D_{N} \\
C_{11} \cdots C_{1 m_{1}} & C_{21} \cdots C_{2 m_{2}} & \cdots & C_{n 1} \cdots C_{n m_{n}}
\end{array}
$$

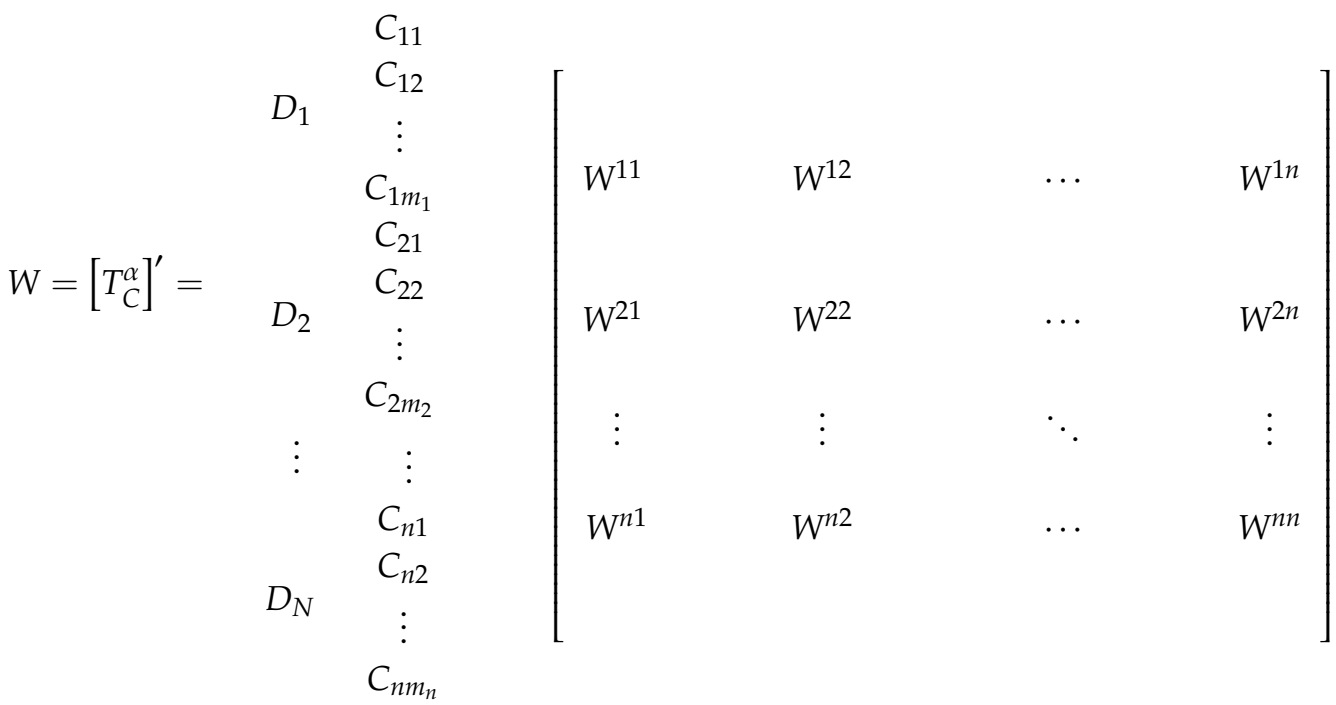

Step 9: Calculate the weighted supermatrix $W_{W}$.

The weighted supermatrix $W_{W}$ can be obtained as shown in Equation (15).

$$
W_{w}=\left[\begin{array}{ccccc}
t_{D}^{\alpha 11} \times W^{11} & t_{D}^{\alpha 12} \times W^{12} & \cdots & \cdots & t_{D}^{\alpha 1 \mathrm{n}} \times W^{1 n} \\
t_{D}^{\alpha 21} \times W^{21} & t_{D}^{\alpha 22} \times W^{22} & \vdots & & \vdots \\
\vdots & \cdots & t_{D}^{\alpha i j} \times W^{i j} & \cdots & t_{D}^{\alpha i n} \times W^{i n} \\
\vdots & & \vdots & & \vdots \\
t_{D}^{\alpha \mathrm{n} 1} \times W^{n 1} & \cdots & t_{D}^{\alpha n j} \times W^{n j} & \cdots & t_{D}^{\alpha n n} \times W^{n n}
\end{array}\right]
$$


Step 10: Calculate the limited weighted supermatrix $W_{C}^{L}$.

The limited weighted supermatrix $W_{L}$ can be attained as shown in Equation (16).

$$
W_{C}^{L}=\lim _{k \rightarrow \infty} W_{w}^{k}, k \in N
$$

The results of limited weighted matrix $W_{C}^{L}$ are the weights of the criteria, which help researchers to conduct the subsequent analysis.

\subsection{Data Collection}

In this study, we aimed to identify the criteria to select top and middle managers from the local labor market for multinational companies. Therefore, we took Taiwan companies as samples and asked managers in Vietnam subsidiaries for their opinions about the dimensions and criteria for hiring local managers.

A modified Delphi questionnaire was established based on the dimensions and criteria in Table 1. In the questionnaire, we asked experts to evaluate the importance of each dimension and criteria with a five-point scale, with 1 for extremely not important and 5 for extremely important.

From the modified Delphi analysis results, the important dimensions and sub-dimensions that most experts reached a consensus on were chosen to develop the DANP questionnaire. In the DANP questionnaire, knowledge-based experts' opinions were used to determine the influential relationships among criteria by a pair-wise comparison from 4 (extremely influential) to 0 (completely non-influential).

Both the modified Delphi and DANP questionnaires were distributed to academic and industrial experts. All the industrial experts are top managers in motor vehicle parts manufacturing companies in Vietnam. They all have abundant experience in hiring employees from the Vietnam labor market. Their expertise and practical experience assisted us in analyzing the causal relationship among selection dimensions and criteria.

For the modified Delphi questionnaires, a total of 20 questionnaires were distributed, and 16 valid questionnaires were collected. For the DANP questionnaires, a total of 20 questionnaires were distributed, and 19 valid questionnaires were collected. For the 20 experts, 8 academic experts were professors in the Department of Business Administration or Human Resources Management. All industrial experts were top managers in subsidiaries of Taiwan companies in Vietnam. The basic information for industry experts is demonstrated in Table 2.

Table 2. Basic information of DANP (decision making and trial evaluation laboratory (DEMATEL)-based analytic network process) DANP industrial experts.

\begin{tabular}{|c|c|c|c|c|c|}
\hline No. & Expert & Area & Position & Job Tenure & Scale of Subsidiary in Vietnam \\
\hline 1 & Ms. Liu & $\begin{array}{c}\text { Dong Nai Province, } \\
\text { Vietnam }\end{array}$ & Administration manager & 21 & 185 \\
\hline 2 & Mr. Yang & $\begin{array}{c}\text { Dong Nai Province, } \\
\text { Vietnam }\end{array}$ & General manager & 17 & 600 \\
\hline 3 & Ms. Huang & $\begin{array}{c}\text { Vinh Phuc Province, } \\
\text { Vietnam }\end{array}$ & General manager & 4 & 435 \\
\hline 4 & Ms. Huang & $\begin{array}{c}\text { Vinh Phuc Province, } \\
\text { Vietnam }\end{array}$ & Vice general manager & 32 & 500 \\
\hline 5 & Mr. Hsu & $\begin{array}{c}\text { Vinh Phuc Province, } \\
\text { Vietnam }\end{array}$ & General manager & 32 & 200 \\
\hline 6 & Mr. Hung & $\begin{array}{c}\text { Dong Nai Province, } \\
\text { Vietnam }\end{array}$ & General manager & 30 & 180 \\
\hline 7 & Mr. Lin & $\begin{array}{c}\text { Vinh Phuc Province, } \\
\text { Vietnam }\end{array}$ & Vice general manager & 40 & 180 \\
\hline 8 & Mr. Wu & $\begin{array}{c}\text { Vinh Phuc Province, } \\
\text { Vietnam }\end{array}$ & General manager & 30 & 4000 \\
\hline
\end{tabular}


Table 2. Cont.

\begin{tabular}{|c|c|c|c|c|c|}
\hline No. & Expert & Area & Position & Job Tenure & Scale of Subsidiary in Vietnam \\
\hline 9 & Mr. Wu & $\begin{array}{c}\text { Vinh Phuc Province, } \\
\text { Vietnam }\end{array}$ & Quality assurance manager & 8 & 3700 \\
\hline 10 & Mr. Wang & $\begin{array}{c}\text { Dong Nai Province, } \\
\text { Vietnam }\end{array}$ & Assistant vice president & 30 & 180 \\
\hline 11 & Mr. Lin & $\begin{array}{c}\text { Dong Nai Province, } \\
\text { Vietnam }\end{array}$ & Vice general manager & 4 & 350 \\
\hline 12 & Mr. Chen & $\begin{array}{c}\text { Vinh Phuc Province, } \\
\text { Vietnam }\end{array}$ & General manager & 20 & 90 \\
\hline
\end{tabular}

\section{Results Analysis}

This study employed the modified Delphi method to determine the selection dimensions and criteria and then, used DANP to obtain the weights of the dimensions and criteria. We employed Excel to perform the calculations in this study.

\subsection{Results of Modified Delphi Method Analysis}

This study employed the modified Delphi method to determine the selection criteria. Four dimensions and fourteen criteria were selected from the literature review. These dimensions and criteria were included in modified Delphi questionnaire to evaluate the importance of the dimensions and criteria and to determine whether all dimensions and criteria could be reserved for further DANP analysis. Twenty experts were invited to fill out the questionnaire through email. For industry experts, we made appointments with them in Vietnam and explained how to complete the questionnaires face-to-face. The analysis results are demonstrated in Table 3. From Table 3, the mean of $C_{2}$, Imitation, was lower than 4 . This indicates that it was not important enough; therefore, it was deleted. All coefficients of variation of dimensions and criteria were less than 0.5 . This indicates that experts reached a consensus on the importance of the dimensions and criteria. Therefore, all dimensions and criteria, except $C_{2}$, were reserved in the DANP questionnaire for further analysis.

Table 3. Results of modified Delphi method.

\begin{tabular}{|c|c|c|c|c|c|c|}
\hline Main Criteria & Criteria & Mean & SD & Coefficient of Variation & Rank of Mean & Result \\
\hline \multirow{4}{*}{ A. Competence } & $\mathrm{A}_{1}$ Core competencies & 4.56 & 0.7 & 0.15 & 3 & \\
\hline & $\begin{array}{c}\mathrm{A}_{2} \text { Managerial } \\
\text { competencies }\end{array}$ & 4.25 & 0.75 & 0.18 & 7 & \\
\hline & $\begin{array}{c}\mathrm{A}_{3} \text { Professional } \\
\text { competencies }\end{array}$ & 4.06 & 0.56 & 0.14 & 13 & \\
\hline & $\mathrm{B}_{1}$ Engagement & 4.88 & 0.33 & 0.05 & 1 & \\
\hline \multirow{5}{*}{ B. Attitude } & $\begin{array}{l}\mathrm{B}_{2} \text { Achievement } \\
\text { motivation }\end{array}$ & 4.38 & 0.78 & 0.18 & 5 & \\
\hline & $\mathrm{B}_{3}$ Trustworthiness & 4.88 & 0.03 & 0.07 & 1 & \\
\hline & $\begin{array}{l}\mathrm{B}_{4} \text { Emotional } \\
\text { commitment }\end{array}$ & 4.19 & 0.63 & 0.15 & 11 & \\
\hline & $\begin{array}{c}\mathrm{B}_{5} \text { Organizational } \\
\text { identification }\end{array}$ & 4.25 & 0.56 & 0.13 & 7 & \\
\hline & $\mathrm{C}_{1}$ Innovation & 4.25 & 0.75 & 0.18 & 7 & \\
\hline \multirow{3}{*}{ C. Intellectual agility } & $\mathrm{C}_{2}$ Imitation & 3.69 & 1.04 & 0.28 & 14 & Deleted \\
\hline & $\mathrm{C}_{3}$ Adaptation & 4.25 & 0.66 & 0.16 & 7 & \\
\hline & $\begin{array}{c}\mathrm{C}_{4} \text { Integration } \\
\mathrm{D}_{1}\end{array}$ & 4.38 & 0.78 & 0.18 & 5 & \\
\hline \multirow[t]{2}{*}{ D. Traits } & $\begin{array}{l}\text { Positivepsychological } \\
\text { capital }\end{array}$ & 4.44 & 0.7 & 0.16 & 4 & \\
\hline & $\begin{array}{c}\mathrm{D}_{2} \text { Internal locus of } \\
\text { control }\end{array}$ & 4.13 & 0.7 & 0.17 & 12 & \\
\hline
\end{tabular}

\subsection{Causal Relationship in DANP}

After determining the dimensions and criteria, a DANP questionnaire analysis was conducted. Knowledge-based experts' opinions are integrated in Tables 4 and 5, as the form of Equation (1). After finding $A_{D}$, the DANP calculation was started. Based on the calculation by Equations (2)-(8), we can derive the prominence and relation of the main dimensions for the selection of the local middle and 
top management in multinational enterprises, as shown in Table 6. We can also derive the prominence and relation of the criteria for the selection of local middle and top management in multinational enterprises, as shown in Table 7.

Table 4. Average matrix $A_{D}$ of dimensions.

\begin{tabular}{ccccc}
\hline Dimension & A & B & C & D \\
\hline A & 0 & 1.632 & 1.737 & 1.053 \\
B & 1.895 & 0 & 1.842 & 1.474 \\
C & 2.000 & 1.316 & 0 & 1.111 \\
D & 1.737 & 1.842 & 1.368 & 0 \\
\hline
\end{tabular}

Table 5. Average matrix $A_{D}$ of criteria.

\begin{tabular}{cccccccccccccc}
\hline Criteria & $\mathbf{A}_{\mathbf{1}}$ & $\mathbf{A}_{\mathbf{2}}$ & $\mathbf{A}_{\mathbf{3}}$ & $\mathbf{B}_{\mathbf{1}}$ & $\mathbf{B}_{\mathbf{2}}$ & $\mathbf{B}_{\mathbf{3}}$ & $\mathbf{B}_{\mathbf{4}}$ & $\mathbf{B}_{\mathbf{5}}$ & $\mathbf{C}_{\mathbf{1}}$ & $\mathbf{C}_{\mathbf{3}}$ & $\mathbf{C}_{\mathbf{4}}$ & $\mathbf{D}_{\mathbf{1}}$ & $\mathbf{D}_{\mathbf{2}}$ \\
\hline $\mathrm{A}_{1}$ & 0 & 2.263 & 2.105 & 1.421 & 1.421 & 1.211 & 1.158 & 1.737 & 1.421 & 1.105 & 1.211 & 0.947 & 0.684 \\
$\mathrm{~A}_{2}$ & 1.474 & 0 & 1.947 & 1.526 & 1.316 & 1.105 & 1.211 & 1.421 & 1.263 & 1.368 & 2.105 & 1.158 & 0.842 \\
$\mathrm{~A}_{3}$ & 1.579 & 1.579 & 0 & 1.474 & 1.368 & 0.895 & 0.842 & 0.895 & 2.105 & 1.421 & 1.737 & 1.053 & 1.158 \\
$\mathrm{~B}_{1}$ & 1.526 & 1.263 & 1.263 & 0 & 1.632 & 1.895 & 1.789 & 1.895 & 1.158 & 1.211 & 1.421 & 1.789 & 1.368 \\
$\mathrm{~B}_{2}$ & 1.526 & 1.737 & 1.895 & 1.684 & 0 & 1.053 & 1.105 & 1.158 & 1.579 & 1.737 & 1.789 & 1.526 & 1.316 \\
$\mathrm{~B}_{3}$ & 1.158 & 1.158 & 0.842 & 1.684 & 0.947 & 0 & 1.789 & 1.737 & .737 & 0.579 & 0.895 & 1.000 & 0.895 \\
$\mathrm{~B}_{4}$ & 1.316 & 1.000 & 1.053 & 1.895 & 1.421 & 1.316 & 0 & 1.947 & 1.000 & 1.368 & 1.211 & 1.474 & 0.895 \\
$\mathrm{~B}_{5}$ & 1.474 & 1.211 & 0.842 & 1.684 & 1.105 & 1.211 & 1.737 & 0 & 0.947 & 1.316 & 1.263 & 1.211 & 0.842 \\
$\mathrm{C}_{1}$ & 1.526 & 1.316 & 1.684 & 0.947 & 1.579 & 0.632 & 0.632 & 0.579 & 0 & 1.211 & 1.789 & 1.105 & 1.105 \\
$\mathrm{C}_{3}$ & 1.211 & 1.211 & 1.053 & 1.053 & 1.211 & 0.789 & 1.053 & 1.000 & 1.053 & 0 & 1.421 & 1.579 & 1.053 \\
$\mathrm{C}_{4}$ & 1.579 & 2.000 & 1.579 & 1.053 & 1.368 & 0.579 & 0.684 & 0.684 & 1.158 & 1.316 & 0 & 1.474 & 1.053 \\
$\mathrm{D}_{1}$ & 1.579 & 1.842 & 1.526 & 1.789 & 1.684 & 1.474 & 1.579 & 1.368 & 1.158 & 1.684 & 1.421 & 0 & 1.421 \\
$\mathrm{D}_{2}$ & 1.053 & 1.474 & 1.421 & 1.632 & 1.895 & 1.105 & .947 & .895 & 1.263 & 1.158 & 1.421 & 1.316 & 0 \\
\hline
\end{tabular}

Table 6. Total relation matrix $\left(T_{D}\right)$ and derived Prominence and Relation of dimensions.

\begin{tabular}{ccccccccc}
\hline Dimensions & $\mathbf{A}$ & $\mathbf{B}$ & $\mathbf{C}$ & $\mathbf{D}$ & $r_{i}$ & $c_{i}$ & $r_{i}+c_{i}$ & $r_{i}-c_{i}$ \\
\hline A. & 1.247 & 1.310 & 1.372 & 1.033 & 4.962 & 6.022 & 10.984 & -1.060 \\
Competence & 1.668 & 1.235 & 1.537 & 1.200 & 5.639 & 5.260 & 10.899 & 0.378 \\
B. Attitude & 1.504 & 1.272 & 1.131 & 1.035 & 4.942 & 5.484 & 10.426 & -0.542 \\
C. Intellectual & 1.54 & 1.444 & .963 & 5.454 & 4.230 & 9.684 & 1.224 \\
$\quad$ agility & 1.604 & 1.444 & 1.444 \\
D. Traits & & & & & & &
\end{tabular}

Table 7. Total relation matrix $\left(T_{D}\right)$ and derived prominence and relation of selection criteria.

\begin{tabular}{cccccccccccccccccc}
\hline Criteria & $\mathbf{A}_{\mathbf{1}}$ & $\mathbf{A}_{\mathbf{2}}$ & $\mathbf{A}_{\mathbf{3}}$ & $\mathbf{B}_{\mathbf{1}}$ & $\mathbf{B}_{\mathbf{2}}$ & $\mathbf{B}_{\mathbf{3}}$ & $\mathbf{B}_{\mathbf{4}}$ & $\mathbf{B}_{\mathbf{5}}$ & $\mathbf{C}_{\mathbf{1}}$ & $\mathbf{C}_{\mathbf{3}}$ & $\mathbf{C}_{\boldsymbol{4}}$ & $\mathbf{D}_{\mathbf{1}}$ & $\mathbf{D}_{\mathbf{2}}$ & $\boldsymbol{r}_{\boldsymbol{i}}$ & $\boldsymbol{c}_{\boldsymbol{i}}$ & $\boldsymbol{r}_{\boldsymbol{i}}+\boldsymbol{c}_{\boldsymbol{i}}$ & $\boldsymbol{r}_{\boldsymbol{i}}-\boldsymbol{c}_{\boldsymbol{i}}$ \\
\hline $\mathrm{A}_{1}$ & 0.463 & 0.600 & 0.574 & 0.548 & 0.527 & 0.425 & 0.453 & 0.502 & 0.482 & 0.480 & 0.544 & 0.473 & 0.384 & 1.638 & 1.526 & 3.164 & 0.112 \\
$\mathrm{~A}_{2}$ & 0.537 & 0.491 & 0.567 & 0.552 & 0.523 & 0.419 & 0.454 & 0.486 & 0.474 & 0.493 & 0.584 & 0.484 & 0.392 & 1.595 & 1.644 & 3.240 & -0.049 \\
$\mathrm{~A}_{3}$ & 0.525 & 0.553 & 0.456 & 0.531 & 0.510 & 0.395 & 0.421 & 0.445 & 0.499 & 0.480 & 0.551 & 0.464 & 0.395 & 1.534 & 1.597 & 3.132 & -0.063 \\
$\mathrm{~B}_{1}$ & 0.577 & 0.595 & 0.572 & 0.520 & 0.576 & 0.490 & 0.519 & 0.547 & 0.501 & 0.521 & 0.591 & 0.550 & 0.446 & 2.651 & 2.659 & 5.310 & -0.008 \\
$\mathrm{~B}_{2}$ & 0.576 & 0.616 & 0.603 & 0.597 & 0.494 & 0.446 & 0.480 & 0.506 & 0.522 & 0.544 & 0.609 & 0.536 & 0.443 & 2.524 & 2.468 & 4.991 & 0.056 \\
$\mathrm{~B}_{3}$ & 0.438 & 0.459 & 0.427 & 0.477 & 0.423 & 0.301 & 0.416 & 0.432 & 0.372 & 0.378 & 0.439 & 0.401 & 0.331 & 2.049 & 2.044 & 4.093 & 0.005 \\
$\mathrm{~B}_{4}$ & 0.510 & 0.520 & 0.503 & 0.552 & 0.509 & 0.417 & 0.381 & 0.497 & 0.442 & 0.475 & 0.521 & 0.482 & 0.380 & 2.356 & 2.238 & 4.594 & 0.117 \\
$\mathrm{~B}_{5}$ & 0.489 & 0.501 & 0.465 & 0.513 & 0.466 & 0.390 & 0.442 & 0.377 & 0.414 & 0.446 & 0.494 & 0.444 & 0.356 & 2.188 & 2.359 & 4.547 & -0.171 \\
$\mathrm{C}_{1}$ & 0.474 & 0.490 & 0.491 & 0.456 & 0.471 & 0.343 & 0.368 & 0.385 & 0.354 & 0.426 & 0.503 & 0.421 & 0.355 & 1.283 & 1.173 & 2.546 & 0.110 \\
$\mathrm{C}_{3}$ & 0.448 & 0.472 & 0.447 & 0.452 & 0.443 & 0.345 & 0.382 & 0.398 & 0.395 & 0.355 & 0.473 & 0.434 & 0.345 & 1.223 & 1.224 & 2.447 & -0.001 \\
$\mathrm{C}_{4}$ & 0.490 & 0.536 & 0.500 & 0.476 & 0.475 & 0.353 & 0.384 & 0.404 & 0.424 & 0.444 & 0.429 & 0.450 & 0.363 & 1.297 & 1.405 & 2.702 & -0.108 \\
$\mathrm{D}_{1}$ & 0.590 & 0.632 & 0.596 & 0.616 & 0.588 & 0.477 & 0.515 & 0.530 & 0.511 & 0.552 & 0.603 & 0.471 & 0.456 & 0.927 & 0.940 & 1.866 & -0.013 \\
$\mathrm{D}_{2}$ & 0.491 & 0.538 & 0.517 & 0.532 & 0.526 & 0.400 & 0.421 & 0.439 & 0.451 & 0.460 & 0.527 & 0.469 & 0.330 & 0.799 & 0.786 & 1.585 & 0.013 \\
\hline
\end{tabular}

Among the dimensions, traits (D) were the primary factor of selecting local middle and top management in multinational enterprises $\left(r_{i}-c_{i}=1.224,\left(r_{i}-c_{i}\right)>0\right.$ means that the dimension is a net 
causer). We speculate that this is because multinational enterprises mainly hope to select local middle and top management with good personality traits that fit the needed job positions. Obstacles are common during the implementation of various business management activities, which further highlights the importance of a comprehensive system for the selection of local middle and top management in multinational enterprises. In another aspect, the prominence and relation table of dimensions for the selection of local middle and top management in multinational enterprises can also facilitate the analysis of the data results.

We can see that competence had the highest prominence $(r i+c i=10.984)$, which indicates that competence takes priority in the selection of local middle and top management in multinational enterprises. The relation of competence was negative ( $r i-c i=-1.060)$, which means that, relatively speaking, competence is a net receiver. We, therefore, suggest that selection decisions begin by managing the net receiver. The relation of attitude is second only to that of traits $(r i-c i=0.378)$. Attitude encompasses the motivation, character, and behavior needed in local middle and top management, so attitude exerts influence on the selection of local middle and top management in multinational enterprises.

In competence, core competencies was the primary influence factor of competence $(r i-c i=0.112)$. We speculate that the selection of local middle and top management in multinational enterprises is still in the development stage, and no complete system exists yet. In practice, there is much dependence on the exchange of the knowledge needed for the selection of local middle and top management between partnering manufacturers. Thus, implementing core competencies is a way of influencing the other two criteria.

In attitude, emotional commitment was the primary factor influencing attitude $\left(r_{i}-c_{i}=0.117\right)$, whereas achievement motivation was the secondary factor $\left(r_{i}-c_{i}=0.056\right)$. We speculate that multinational enterprises require local middle and top management to be willing to devote effort to the company, contribute their strengths, and actively assist others; they want management to demonstrate their commitment and engagement and be extremely committed to the company. In practice, such managers indeed have a strong sense of mission towards their companies and are more willing to protect the company's assets. In another aspect, the selected local middle and top management must also have certain standards; whether they were hired externally or promoted from within, they must aim to pursue work of greater importance and value, work hard for their future's sake, and strive for a better quality of life. In practice, such managers are extremely hands-on and endeavor to do everything to the best of their ability.

In intellectual agility, innovation was the primary factor $(r i-c i=0.110)$. This shows that when multinational enterprises are selecting local middle and top management, they attach a great deal of importance to whether interest is shown in searching for new technologies, new procedures, new knowledge, new skills, and new product ideas. As advances in technology are made every day, managers must continuously update their knowledge and skills to keep up with the changes.

In traits, an internal locus of control was the main factor influencing the selection of local middle and top management in multinational enterprises $(r i-c i=0.013)$. We infer that middle and top management with an internal locus of control are independent and reasonable, have stable and unaggressive personalities, and have the ability to focus on dealing with various matters. In practice, such local middle and top management have even temperaments and do things with tact no matter what work they are assigned to.

This study examined the selection of local middle and top management in multinational enterprises from the perspective of human capital. Based on a literature review and a questionnaire survey administered to academic experts and industry experts in Taiwanese companies in Vietnam, we identified the dimensions and criteria for the selection of local middle and top management in multinational enterprises.

Using DANP, we determined the weights of these dimensions and criteria to determine which dimensions multinational enterprises considered important and the degree to which they were 
important. Based on the data we collected, we established causal relationships among the dimensions and ranked the main dimensions and criteria by their priority level.

The results indicated that, in the selection of local middle and top management, multinational enterprises valued competence the most, followed by intellectual agility, attitude, and finally, traits. These results are consistent with the current practices. The selection of local middle and top management in multinational enterprises should follow local culture and norms, and competence takes priority. A selection system should be properly established for evaluation to increase the chance that local middle and top management hired externally or promoted from within will efficiently perform their duties in the company.

The causal relationships that were found revealed that traits was the criterion with the greatest relation. Thus, even though the weights of competence and intellectual agility were greater than that of traits, traits still took priority because they influence competence and intellectual agility. Systematic personality tests can efficiently manage the overall recruitment operations of local middle and top management in multinational enterprises, and only through competence, attitude, and intellectual agility can concepts in organizational culture and sustainability be incorporated into the internal basis of all local middle and top management.

\subsection{Weights of Selection Dimension and Criteria}

Having determined the relationship structure of selection dimension and criteria, the influential weights of the dimensions and criteria can be attained by Equations (10)-(16). Table 8 demonstrates the unweighted supermatrix $(\boldsymbol{W})$ andTable 9 demonstrates the weighted supermatrix $\left(\boldsymbol{W}_{w}\right)$. Based on the DANP calculation results, we derived the weights of the dimensions and criteria for the selection of local middle and top management in multinational enterprises, which are shown in Table 10.

From Table 10, competence (0.284) was considered the most important of the main dimensions in multinational enterprises, followed by intellectual agility $(0.260)$, attitude $(0.251)$, and traits $(0.203)$. We infer that for multinational enterprises, it is imperative to know whether local middle and top management have the competence to deal with the ever-changing environment. In terms of intellectual agility, integration, adaptation, and innovation are crucial in emerging countries, mainly because the collective is more important than the individual in emerging countries. Only a manager that can integrate people and things is able to direct corporate matters. With regard to attitude, multinational enterprises must cultivate middle and top management with an engaging spirit to generate achievement motivation and promote emotional commitment to the enterprises. Thus, competence, intellectual agility, and attitude are the dimensions for the selection of local middle and top management in multinational enterprises.

Among the criteria, positive psychological capital (0.112) was the most important; managerial competencies (0.098), integration (0.095), and professional competencies (0.094) were the second, third, and fourth most important, and core competencies (0.092) and internal locus of control (0.092) were the fifth most important. We infer that positive psychological capital indicates that local middle and top management must have confidence, hope, optimism, and resilience and be able to adjust their own psychological state at any time in the event of adversity or difficulty in the work environment. In practice, individuals with positive psychological capital are better able to face unexpected situations and self-adjust psychologically.

As for managerial competencies, middle and top management must have the ability to gather, integrate, and deploy individual resources (labor, company, and relations) of the company and meet customer needs in various business matters. Local middle and top management with the ability to integrate know their own advantages and disadvantages, find the weaknesses of the competitors, and collect data and make use of resources to open up better opportunities for the company. Local middle and top management with professional competencies take to this industry or position like a duck to water. Those with core competencies have a complete understanding of the company. Those with an 
internal locus of control are independent and reasonable and have the ability to focus on promoting and developing various business matters.

Table 8. Unweighted supermatrix $W$.

\begin{tabular}{cccccccccccccc}
\hline & $\mathbf{A}_{\mathbf{1}}$ & $\mathbf{A}_{\mathbf{2}}$ & $\mathbf{A}_{\mathbf{3}}$ & $\mathbf{B}_{\mathbf{1}}$ & $\mathbf{B}_{\mathbf{2}}$ & $\mathbf{B}_{\mathbf{3}}$ & $\mathbf{B}_{\mathbf{4}}$ & $\mathbf{B}_{\mathbf{5}}$ & $\mathbf{C}_{\mathbf{1}}$ & $\mathbf{C}_{\mathbf{3}}$ & $\mathbf{C}_{\mathbf{4}}$ & $\mathbf{D}_{\mathbf{1}}$ & $\mathbf{D}_{\mathbf{2}}$ \\
\hline $\mathrm{A}_{1}$ & 0.283 & 0.337 & 0.342 & 0.331 & 0.321 & 0.331 & 0.333 & 0.336 & 0.326 & 0.328 & 0.321 & 0.324 & 0.318 \\
$\mathrm{~A}_{2}$ & 0.366 & 0.308 & 0.360 & 0.341 & 0.343 & 0.346 & 0.339 & 0.344 & 0.337 & 0.345 & 0.351 & 0.348 & 0.348 \\
$\mathrm{~A}_{3}$ & 0.351 & 0.355 & 0.297 & 0.328 & 0.336 & 0.323 & 0.328 & 0.320 & 0.337 & 0.327 & 0.328 & 0.328 & 0.334 \\
$\mathrm{~B}_{1}$ & 0.223 & 0.227 & 0.231 & 0.196 & 0.237 & 0.233 & 0.234 & 0.234 & 0.225 & 0.224 & 0.228 & 0.226 & 0.230 \\
$\mathrm{~B}_{2}$ & 0.215 & 0.215 & 0.222 & 0.217 & 0.196 & 0.206 & 0.216 & 0.213 & 0.233 & 0.219 & 0.227 & 0.216 & 0.227 \\
$\mathrm{~B}_{3}$ & 0.173 & 0.172 & 0.172 & 0.185 & 0.177 & 0.147 & 0.177 & 0.178 & 0.170 & 0.171 & 0.169 & 0.175 & 0.173 \\
$\mathrm{~B}_{4}$ & 0.185 & 0.187 & 0.183 & 0.196 & 0.190 & 0.203 & 0.162 & 0.202 & 0.182 & 0.189 & 0.184 & 0.189 & 0.182 \\
$\mathrm{~B}_{5}$ & 0.204 & 0.200 & 0.193 & 0.206 & 0.201 & 0.211 & 0.211 & 0.172 & 0.190 & 0.197 & 0.193 & 0.194 & 0.189 \\
$\mathrm{C}_{1}$ & 0.320 & 0.306 & 0.326 & 0.311 & 0.311 & 0.313 & 0.307 & 0.306 & 0.276 & 0.323 & 0.327 & 0.307 & 0.314 \\
$\mathrm{C}_{3}$ & 0.319 & 0.318 & 0.314 & 0.323 & 0.325 & 0.318 & 0.330 & 0.330 & 0.332 & 0.290 & 0.342 & 0.331 & 0.320 \\
$\mathrm{C}_{4}$ & 0.361 & 0.377 & 0.360 & 0.366 & 0.364 & 0.369 & 0.362 & 0.365 & 0.392 & 0.387 & 0.331 & 0.362 & 0.366 \\
$\mathrm{D}_{1}$ & 0.552 & 0.553 & 0.540 & 0.552 & 0.548 & 0.548 & 0.559 & 0.555 & 0.542 & 0.557 & 0.554 & 0.508 & 0.587 \\
$\mathrm{D}_{2}$ & 0.448 & 0.447 & 0.460 & 0.448 & 0.452 & 0.452 & 0.441 & 0.445 & 0.458 & 0.443 & 0.446 & 0.492 & 0.413 \\
\hline
\end{tabular}

Table 9. Weighted supermatrix $W_{w}$.

\begin{tabular}{|c|c|c|c|c|c|c|c|c|c|c|c|c|c|}
\hline & A1 & 2 & A3 & B1 & B2 & B3 & B4 & B5 & $\mathrm{C} 1$ & C3 & C4 & D1 & D2 \\
\hline 1 & .071 & 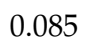 & 86 & , & 0.095 & 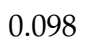 & 0.098 & 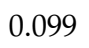 & 0.099 & 0.100 & 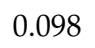 & 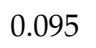 & 093 \\
\hline A2 & & & 0.090 & & & 102 & & & & 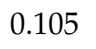 & & & 102 \\
\hline A3 & & & V7. & & & 95 & & & & 100 & & & .098 \\
\hline B1 & 59 & 0.060 & 0.061 & 0.043 & 52 & 0.051 & & 0.051 & & 0.058 & & 0.060 & 0.061 \\
\hline B2 & 7 & 0 & 0.058 & & & 0.045 & & & & 0.056 & & & 0.060 \\
\hline B3 & 0 & & 0.045 & & & 0.032 & & & & .044 & & & 0.046 \\
\hline B4 & & 0.049 & 0.048 & 0.043 & & 0.044 & & & & 0.049 & & & 0.048 \\
\hline B5 & & 0.053 & 0.051 & 0.045 & 0.044 & 0.046 & 0.046 & & & 0.051 & 0.050 & 0.051 & 0.050 \\
\hline $\mathrm{C} 1$ & & & & & & & & & & 0.074 & & & 0.083 \\
\hline C3 & 888 & 0.088 & 0.087 & 0.088 & 0.089 & 0.087 & 0.090 & 0.090 & 0.0 & 0.066 & 0.078 & 0.088 & 0.085 \\
\hline $\mathrm{C} 4$ & 0100 & 0.104 & 0.100 & 0.100 & 0.099 & 0.101 & 0.099 & 0.099 & 0.090 & 0.089 & 0.076 & 0.096 & 0.097 \\
\hline D1 & & & & & & & & & & & & & 0.104 \\
\hline D2 & 0.093 & 0.093 & 0.096 & 0.095 & 0.096 & 0.096 & 0.094 & 0.095 & 0.096 & 0.093 & 0.093 & 0.087 & 0.073 \\
\hline
\end{tabular}

Table 10. DANP weights of dimensions and criteria.

\begin{tabular}{|c|c|c|c|c|c|}
\hline Dimensions & Weight & Ranking & Criteria & Global Weight & Over Ranking \\
\hline A. Competence & 0.284 & 1 & $\mathrm{~A}_{2}$ Managerial competencies & 0.098 & 2 \\
\hline \multirow{4}{*}{ B. Attitude } & \multirow{4}{*}{0.251} & \multirow{4}{*}{3} & $\mathrm{~B}_{1}$ Engagement & 0.057 & 9 \\
\hline & & & $\mathrm{B}_{2}$ Achievement motivation & 0.055 & 10 \\
\hline & & & $\mathrm{B}_{3}$ Trustworthiness & 0.043 & 13 \\
\hline & & & $\mathrm{B}_{5}$ Organizational identification & 0.049 & 11 \\
\hline \multirow{3}{*}{ C. Intellectual agility } & \multirow{3}{*}{0.260} & \multirow{3}{*}{2} & $\mathrm{C}_{1}$ Innovation & 0.081 & 8 \\
\hline & & & $\mathrm{C}_{3}$ Adaptation & 0.084 & 7 \\
\hline & & & $\mathrm{C}_{4}$ Integration & 0.095 & 3 \\
\hline D. Traits & 0.203 & 4 & $\mathrm{D}_{1}$ Positivepsychological capital & 0.112 & 1 \\
\hline
\end{tabular}

\subsection{Discussion and Managerial Applicatiom}

This study employed empirical analysis to identify the selection factors of local middle and top management in multinational enterprises from the perspective of human capital, thereby providing a whole new way of thinking and a selection decision model. Recruitment among organizations 
utilizes the differences among companies to obtain and accumulate human capital and reduce human capital risk [65]. Thus, establishing a good human capital selection structure as well as strengthening and accumulating human capital in enterprises can provide direction and guidance to multinational enterprises in selecting employees from the perspective of human capital so that they can gain competitive advantages that enabled them to surpass their competitors and accumulate human capital [65].

This investigation of the factors influencing the selection of local middle and top management in multinational enterprises from the perspective of human capital can divert more attention to human capital. This also increases the amount of importance attached to the qualifications needed for local middle and top management, help enterprises understand the relationships among the knowledge, combination of skills and abilities, innovation, and performance of employees selected from the perspective of human capital, and further help enterprises categorize selection factors to provide managers in multinational enterprises with reference when they are selecting crucial talent. Selection from the perspective of human capital is also a dynamic system. Managers are responsible for revising the system and taking action. For instance, recruitment impacts not only performance evaluation but also other human capital variables, so enterprises must keep an eye on the changes in the talent flow in the market [66].

The contributions of this study in selecting middle and top management from the perspective of human capital include (1) using the perspective of human capital to help companies obtain scarce middle and top management in the labor market, (2) establishing selection mechanisms that promote competition between individuals with substantial and scarce human resources as hiring qualified middle and top management can increase the financial proceeds from the employment relationship, and (3) enhancing the local manager's bargaining power in the division of these proceeds to adjust their relative value in human capital [26]. Selection can help enterprises reduce the potential financial and strategic burdens imposed by employing the wrong middle and top management, including productivity losses, reduced revenue, and talent replacement costs [65].

Multinational enterprises are in even greater need of properly implementing human development policies, such as education and training, performance evaluation, job changes, and personal career development. To be able to take root and maintain a steady pace in emerging countries and markets, the localization of middle and top management exerts a significant impact [66]. Although employee localization is already currently underway and locals already account for the majority of middle managers, reducing the ratio of expatriate executives and improving local employees are still ongoing efforts in multinational enterprises in emerging countries. We, therefore, suggest the two following measures that can be taken in management practices.

\subsubsection{Selecting Mangers Inside the Enterprises}

The consideration of multinational enterprises in appointing local middle and top management is because the cost of appointing supervisors in their parent-countries is relatively high, and the economic benefits of local talents in local countries have always existed. Local talents have a deeper understanding of the local cultural, legal, economic, and political environment than the head of the home country.

In the cultivation of local talent, enterprises must first understand the employment conditions of local middle and top management and the economic structure of different industries. Certain companies may have significantly high or low performance; those with better performance focus more on accumulating human capital [67].

The selection of human capital in multinational enterprises considers the culture and language of the local employees, the spatial and temporal operations of their cognitive abilities, and the distant environment. Multinational enterprises must have a more detailed understanding of the uniqueness of human capital. The differences between the human capital in the parent-company and that in certain regions, strategic training, and promotion channels must be considered during annual inventories and 
the planning of corporate human capital. Various complete education and training programs should be given to cultivate employees that will be crucial in the future to cope with future labor structure changes in the industry. The supervisors of different departments can be rotated internally to groom them as candidates for future middle and top management in preparation for future organizational expansions. Enterprises can enhance the abilities of their employees through training and construct a high performance work system to develop their human capital and competitive advantages [14].

\subsubsection{Selecting Managers Outside the Enterprises}

Human capital flows between different organizations, particularly pertaining to high-quality employees [68]. When enterprises cannot retain employees of higher quality, they can obtain suitable talent through different channels. Despite the import of human capital from scarce middle and top management in the labor market, a sound selection method is still needed to identify which candidate can meet the company's expectations [26].

\subsubsection{Search Candidates from Industry Associations}

Industry associations are established by select companies in the same industry for corporate socialization and personnel development. Employees can participate in various industry association activities early on in their career development, such as competitions, reading clubs, and work exchanges, so that the employees can get to know the organizational cultures of the companies in the industry association. If any companies or middle and top management have needs involving job changes, they can benefit from one another in the association.

\subsubsection{Search Candidates from School and University Cooperation}

To establish, maintain, and deepen their relations with local schools or universities, companies that are hiring will often provide resources, such as scholarships, research funding, or professor research grants, or establish seed foundations or outreach centers (such as an engineering center) on campus so that they have a wider selection of talent from the graduates. Students can also get to know different companies through academia-industry cooperation and, in turn, identify with their corporate culture and values. To gain human capital advantages, the influx of human capital must complement the attributes of the organization so as to maintain two-way communication and competitive advantages for the employees and the companies [65].

Employees should start at the bottom in order to grow in the future. The greatest shortcoming of hiring a manager from the outside is that they do not know the basic operations and may be unrealistic unless they are fairly familiar with the industry environment. Thus, if there is an entry-level employee with the capacity to go further up, rotations and other arrangements should be made to increase their work experience and teach them how to manage project work. A middle and top management candidate, either promoted from within or hired externally, needs to learn the various philosophies, cultures, and business documents of the company, comprehend the essence of the wisdom of the higher-ups, and imperceptibly incorporate them into his or her own methods so that he or she is better suited to the position.

Taiwan-based multinational enterprises have been operating in Vietnam for many years, and it is inevitable that their human resource management system will progress toward localization. Only with suitable selection decisions can they compete in the human resource market using human capital strategies. Appropriate staffing and developing their corporate social responsibility will help Taiwanese enterprises achieve sustainable operations and create value in multinational markets.

\section{Conclusions}

Applications of human capital to management have typically involved studies of the relationship between human capital and organizational performance [69]. Human capital is the key to creating competitive advantages for corporations [70]. Human capital is the capacity of production skills, 
expertise, health, and professional knowledge in labor. It is accumulated through a series of investment decisions. Investments in human capital are the opportunity costs of individual time [71].

The main subjects of this study were Taiwan-based multinational motor vehicle parts manufacturing companies in Vietnam, and the participants included academic and industry experts. The research topic can also be applied to other emerging countries, such as Cambodia or Myanmar, to coordinate with the New Southbound Policy of the government of Taiwan and provide better policies. Thus, the research topic can also be applied to other industries to enhance its applicability.

The dimensions used in this study were designed by foreign researchers. For their suitability to the content of this study, we conducted a literature review to identify the suitable dimensions, made adjustments based on the suggestions of academic and industry experts, and created a scale in Mandarin for the practices and context of multinational enterprises. However, the imitation did not meet expectations, which indicates that the compilation of the dimensions for the scale was still affected by cultural differences and that the respondents may have had different views and perceptions of the question items. We suggest that similar studies in the future make revisions or select a different theoretical perspective to develop the questionnaire to better fit the needs and context of multinational enterprises.

We suggest that future studies investigating the selection of local middle and top management for multinational enterprises administer personality tests, such as the Holland Code Test, the Professional Dynametric Programs (P.D.P), the Big Five Personality Trait, and the Enneagram personality test as working in a multinational enterprise involves the cultural differences of different countries, communication barriers, language barriers, and power distance. Multinational enterprises, therefore, hope that local middle and top management who are hired externally or promoted from within can adjust their mental state no matter what obstacles or difficulties they encounter in the work environment.

Author Contributions: I.-C.H. develops the idea, motivation, and question of the paper. Y.-J.S. outlined the manuscript and writing - original draft preparation F.-Y.P. outlined and revised the manuscript, made substantial contributions to the design of this study and contributed to the discussion. All authors have read and agreed to the published version of the manuscript.

Funding: This research received no external funding.

Acknowledgments: The authors would like to express their sincere gratitude to the editor and the anonymous reviewers for their insightful and constructive comments.

Conflicts of Interest: The authors declare no conflict of interest.

\section{References}

1. Vidal-Salazar, M.D.; Cordón-Pozo, E.; Ferrón-Vilchez, V. Human resource management and developing proactive environmental strategies: The influence of environmental training and organizational learning. Hum. Resour. Manag. 2012, 51, 905-934. [CrossRef]

2. Cascio, W.F.; Boudreau, J.W. The search for global competence: From international HR to talent management. J. World Bus. 2016, 51, 103-114. [CrossRef]

3. Youndt, M.A.; Subramaniam, M.; Snell, S.A. Intellectual Capital Profiles: An Examination of Investments and Returns*. J. Manag. Stud. 2004, 41, 335-361. [CrossRef]

4. Alpkan, L.; Bulut, C.; Gunday, G.; Ulusoy, G.; Kilic, K. Organizational support for intra-preneurship and its interaction with human capital to enhance innovative Performance. Manag. Decis. 2010, 48, 732-755. [CrossRef]

5. Segal, G.; Borgia, D.; Schoenfeld, J. Founder human capital and small firm performance: An empirical study of founder-managed natural food stores. J. Manag. Market Res. 2010, 4, 1-10.

6. Samad, S. Assessing the Contribution of Human Capital on Business Performance. Int. J. Trade, Econ. Financ. 2013, 4, 393-397. [CrossRef]

7. Farndale, E.; Pai, A.; Sparrow, P.; Scullion, H. Balancing individual and organizational goals in global talent management: A mutual-benefits perspective. J. World Bus. 2014, 49, 204-214. [CrossRef] 
8. Law, K.S.; Song, L.J.; Wong, C.S.; Chen, D. The antecedents and consequences of successful localization. J. Int. Bus. Stud. 2009, 40, 1359-1373. [CrossRef]

9. Dörrenbächer, C.; Geppert, M. Subsidiary staffing and initiative-taking in multinational corporations. Pers. Rev. 2010, 39, 600-621. [CrossRef]

10. Collings, D.G.; Scullion, H.; Dowling, P. Global staffing: A review and thematic research agenda. Int. J. Hum. Resour. Manag. 2009, 20, 1253-1272. [CrossRef]

11. Kang, H.; Shen, J. International recruitment and selection practices of South Korean multinationals in China. Int. J. Hum. Resour. Manag. 2013, 24, 3325-3342. [CrossRef]

12. Li, C.S.J.; Lee, P.Y.; Liou, J.J. Exploring the staff localization of Taiwanese MNC subsidiaries in China: Effects of size, operation time, location, and local-market focus. J. Bus. Res. 2018, 88, 20-27. [CrossRef]

13. Nigam, R. Climbing up the Performance Ladder: A Conceptual Framework for Emerging Country Multinationals. Int. J. Bus. Manag. 2010, 5, 13-25. [CrossRef]

14. Collings, D.G.; Mellahi, K.; Cascio, W.F. Global talent management and performance in multinational enterprises: A multilevel perspective. J. Manag. 2018, 45, 540-566. [CrossRef]

15. Schultz, T.W. Investment in Human Capital. Am. Econ. Rev. 1961, 51, 1-17.

16. Oladipo, J.A.; Abdulkadir, D.S. Strategic human resource management and organizational performance in the Nigerian manufacturing sector: An empirical investigation. Int. J. Bus. Manag. 2011, 6, 46-56.

17. Wright, P.M.; Mcmahan, G.C. Exploring human capital: Putting 'human' back into strategic human resource management. Hum. Resour. Manag. J. 2011, 21, 93-104. [CrossRef]

18. Bowman, C.; Hird, M. A Resource-based View of Talent Management. In Strategic Talent Management, Contemporary Issues in International Context, 2nd ed.; Sparrow, P., Scullion, H., Tarique, I., Eds.; Cambridge University Press: Cambridge, UK, 2014; pp. 73-86.

19. Delery, J.E.; Roumpi, D. Strategic human resource management, human capital and competitive advantage: Is the field going in circles? Hum. Resour. Manag. J. 2017, 27, 1-21. [CrossRef]

20. Linden, G.; Teece, D.J. Managing Expert Talent. In Strategic Talent Management: Contemporary Issues in International Context, 2nd ed.; Sparrow, P., Scullion, H., Tarique, I., Eds.; Cambridge University Press: Cambridge, UK, 2014; pp. 87-116.

21. Roos, J.; Roos, G.; Dragonetti, N.C.; Edvinsson, L. Intellectual Capital: Navigating the New Business Landscape; MACMILLAN: London, UK, 1997.

22. Roos, G. Knowledge management, intellectual capital, structural holes, economic complexity and national prosperity. J. Intellect. Cap. 2017, 18, 745-770. [CrossRef]

23. Roos, G.; Pike, S.; Fernström, L. Managing Intellectual Capital in Practice, 1st ed.; Routledge: London, UK, 2007.

24. Ployhart, R.E.; Moliterno, T.P. Emergence of the Human Capital Resource: A Multilevel Model. Acad. Manag. Rev. 2011, 36, 127-150. [CrossRef]

25. Ployhart, R.E.; Nyberg, A.J.; Reilly, G.; Maltarich, M.A. Human Capital Is Dead; Long Live Human Capital Resources! J. Manag. 2014, 40,371-398. [CrossRef]

26. Mackey, A.; Molloy, J.C.; Morris, S.S. Scarce Human Capital in Managerial Labor Markets. J. Manag. 2014, 40, 399-421. [CrossRef]

27. Wang, Y.F.; Lai, S.D.; Lee, Y.C. Exploring competencies for entrepreneurs of local food stores. J. Leis. Tour. Ind. Res. 2010, 5, 70-90.

28. Christian, M.S.; Garza, A.S.; Slaughter, J.E. Work Engagement: A Quantitative Review and Test of Its Relations with Task and Contextual Performance. Pers. Psychol. 2011, 64, 89-136. [CrossRef]

29. Schoen, J.L. Effects of implicit achievement motivation, expected evaluations, and domain knowledge on creative performance. J. Organ. Behav. 2014, 36, 319-338. [CrossRef]

30. Noval, L.J.; Stahl, G.K. Accounting for Proscriptive and Prescriptive Morality in the Workplace: The Double-Edged Sword Effect of Mood on Managerial Ethical Decision Making. J. Bus. Ethics 2015, 142, 589-602. [CrossRef]

31. Sendjaya, S.; Pekerti, A.; Härtel, C.; Hirst, G.; Butarbutar, I. Are authentic leaders always moral? the role of machiavellianism in the relationship between authentic leadership and morality. J. Bus. Ethics 2016, 133, 125-139. [CrossRef]

32. Thomas, D.C.; Ravlin, E.C. Responses of employees to cultural adaptation by a foreign manager. J. Appl. Psychol. 1995, 80, 133-146. [CrossRef] 
33. Diribarne, P. Motivating workers in emerging countries: Universal tools and local adaptations. J. Organ. Behav. 2002, 23, 243-256. [CrossRef]

34. Hampson, S.E.; Goldberg, L.R. A first large cohort study of personality trait stability over the 40 years between elementary school and midlife. J. Pers. Soc. Psychol. 2006, 91, 763-779. [CrossRef]

35. Luthans, F.; Luthans, K.W.; Luthans, B.C. Positive psychological capital: Beyond human and social capital. Bus. Horiz. 2004, 47, 45-50. [CrossRef]

36. Luthans, F.; Avolio, B.J.; Avey, J.B.; Norman, S.M. Positive Psychological Capital: Measurement and Relationship with Performance and Satisfaction. Pers. Psychol. 2007, 60, 541-572. [CrossRef]

37. Boone, C.; Olffen, W.V.; Witteloostuijn, A.V. Team locus-of-control composition, leadership structure, information acquisition, and financial performance: A business simulation study. Acad. Manag. J. 2005, 48, 889-909. [CrossRef]

38. Cheng, K.C. The impact of level of sunk cost and locus of control on the willingness to continue investment: Mediated effect of risk perception. J. Manag. Bus. Res. 2014, 31, 371-388.

39. Lee, T.Z.; Lee, C.C.; Tseng, Y.F. A study of the relationships among organizational career management of the large enterprises, individual career planning, personality traits, and job satisfaction. J. Hum. Resour. Manag. $2005,5,53-76$.

40. Guimaraes, T.A.; Borges-Andrade, J.E.; Machado, M.D.S.; Vargas, M.R.M. Forecasting core competencies in an R\&D environment. $R$ D Manag. 2001, 31, 249-255.

41. Boermans, M.A.; Roelfsema, H. The effects of managerial capabilities on export, FDI and innovation: Evidence from Indian firms. Asian Bus. Manag. 2013, 12, 387-408. [CrossRef]

42. Bolmiri, S.H.; Gardoon, A.; Kahkesh, P.H. Study of the effect of management ability on earnings quality. Int. J. Manag. Acc. Econ. 2016, 3, 319-335.

43. Wu, H.P.; Lu, L.; Wu, S.J. High-Performing Employees' Profiles and Competencies: A Listed Computer Systems Company in Taiwan. J. Hum. Resour. Manag. 2010, 10, 1-26.

44. Lee, C.S.; Ke, L.I.; Liu, D.Y. A Study on the Professional Competence Domain and Index of Procurement Supervisor in International Hotels. J. Sport Leis. Hosp. Res. 2012, 7, $27-46$.

45. Demerouti, E.; Bakker, A.B.; Gevers, J.M. Job crafting and extra-role behavior: The role of work engagement and flourishing. J. Vocat. Behav. 2015, 91, 87-96. [CrossRef]

46. Shu, C.Y.; Jhan, J.Y. Investigating the relationship between authoritarian leadership and subordinate's emotional labor. J. Hum. Resour. Manag. 2016, 14, 31-55.

47. Tang, Y.T. The Relationships among Transformational Leadership, Work Motivation and Employee Innovative Behavior. J. Hum. Resour. Manag. 2006, 6, 47-66.

48. Meyer, J.P.; Stanley, D.J.; Jackson, T.A.; Mcinnis, K.J.; Maltin, E.R.; Sheppard, L. Affective, normative, and continuance commitment levels across cultures: A meta-analysis. J. Vocat. Behav. 2012, 80, 225-245. [CrossRef]

49. Waeyenberg, T.V.; Decramer, A.; Desmidt, S.; Audenaert, M. The relationship between employee performance management and civil servants' turnover intentions: A test of the mediating roles of system satisfaction and affective commitment. Public Mana. Rev. 2016, 19, 747-764. [CrossRef]

50. Mohammed, F.; Eleswed, M. Job satisfaction and organizational commitment: A correlational study in Bahrain. Int. J. Bus. Human Tech. 2013, 3, 44-53.

51. Boon, C.; Kalshoven, K. How High-Commitment HRM Relates to Engagement and Commitment: The Moderating Role of Task Proficiency. Hum. Resour. Manag. 2014, 53, 403-420. [CrossRef]

52. Choi, J.N.; Price, R.H. The effects of person-innovation fit on individual responses to innovation. J. Occup. Organ. Psychol. 2005, 78, 83-96. [CrossRef]

53. Matías-Reche, F.; García-Morales, V.J.; Martín-Tapia, I. Staffing Services Quality and Innovativeness in Pharmaceutical Companies. Int. J. Sel. Assess. 2010, 18, 342-350. [CrossRef]

54. Williamson, I.O.; Cable, D.M. Organizational Hiring Patterns, Interfirm Network Ties, and Interorganizational Imitation. Acad. Manag. J. 2003, 46, 349-358.

55. Bandura, A. Human agency in social cognitive theory. Am. Psychol. 1989, 44, 1175-1184. [CrossRef] [PubMed]

56. Hurley, R.F.; Hult, G.T.M. Innovation, Market Orientation, and Organizational Learning: An Integration and Empirical Examination. J. Mark. 1998, 62, 42-54. [CrossRef]

57. Stan, M.; Puranam, P. Organizational adaptation to interdependence shifts: The role of integrator structures. Strateg. Manag. J. 2017, 38, 1041-1061. [CrossRef] 
58. Peterson, S.J.; Luthans, F.; Avolio, B.J.; Walumbwa, F.O.; Zhang, Z. Psychological Capital and Employee Performance: A Latent Growth Modeling Approach. Pers. Psychol. 2011, 64, 427-450. [CrossRef]

59. Murry, J.W.; Hammons, J.O. Delphi: A Versatile Methodology for Conducting Qualitative Research. Rev. High Educ. 1995, 18, 423-436. [CrossRef]

60. Chen, J.; Chen, I. Critical creativity dimensionsfor students in higher education: Taking the interrelationship effect among dimensions into account. Qual. Quant. 2011, 46, 1057-1075. [CrossRef]

61. Hsu, C.H.; Wang, F.K.; Tzeng, G.H. The best vendor selection for conducting the recycled material based on a hybrid MCDM model combining DANP with VIKOR. Resour. Conserv. Recycl. 2012, 66, 95-111. [CrossRef]

62. Hsu, C.C.; Liou, J.J.; Chuang, Y.C. Integrating DANP and modified grey relation theory for the selection of an outsourcing provider. Expert. Syst. Appl. 2013, 40, 2297-2304. [CrossRef]

63. Chang, D.S.; Chen, S.H.; Hsu, C.W.; Hu, A.; Tzeng, G.H. Evaluation Framework for Alternative Fuel Vehicles: Sustainable Development Perspective. Sustainability 2015, 7, 11570-11594. [CrossRef]

64. Wu, H.H.; Chang, S.Y. A case study of using DEMATEL method to identify critical factors in green supply chain management. Appl. Math. Comput. 2015, 256, 394-403.

65. Brymer, R.A.; Molloy, J.C.; Gilbert, B.A. Human Capital Pipelines. J. Manag. 2013, 40, 483-508. [CrossRef]

66. Yu, M.C.; Li, S.N. Empirical Study of Human Resource Management Practices and Managers' Successful Localizations in Taiwanese Companies' Subsidiaries in China: The Moderating Effects of Organizational Trust and Cultural Difference. J. Labor Stud. 2016, 18, 1-22.

67. Campbell, B.A.; Coff, R.; Kryscynski, D. Rethinking Sustained Competitive Advantage from Human Capital. Acad. Manag. Rev. 2012, 37, 376-395. [CrossRef]

68. Reilly, G.; Nyberg, A.J.; Maltarich, M.; Weller, I. Human Capital Flows: Using Context-Emergent Turnover (CET) Theory to Explore the Process by Which Turnover, Hiring, and Job Demands Affect Patient Satisfaction. Acad. Manag. J. 2014, 57, 766-790. [CrossRef]

69. Jin, Y.; Hopkins, M.M.; Wittmer, J.L.S. Linking human capital to competitive advantages: Flexibility in a manufacturing firms supply chain. Hum. Resour. Manag. 2010, 49, 939-963. [CrossRef]

70. Bhattacharya, M.; Doty, D.H.; Garavan, T. The Organizational Context and Performance Implications of Human Capital Investment Variability. Hum. Resour. Dev. Q 2014, 25, 87-113. [CrossRef]

71. Goldin, C. Human Capital. In Handbook of Cliometrics; Claude, D., Michael, H., Eds.; Springer: Heidelberg, Germany, 2016; pp. 55-86.

(C) 2020 by the authors. Licensee MDPI, Basel, Switzerland. This article is an open access article distributed under the terms and conditions of the Creative Commons Attribution (CC BY) license (http://creativecommons.org/licenses/by/4.0/). 